\title{
RESENHA
}

\section{Ministério Público e Políticas de Saúde ${ }^{1}$}

Oswaldo José Barbosa Silva²

Luciano Moreira de Oliveira é mestre em saúde pública pela UFMG, professor da disciplina Direito à Saúde da Fundação Escola Superior do Ministério Público de Minas Gerais e Promotor de Justiça do Ministério Público de Minas Gerais (MPMG).

A obra apresenta a matriz teórica que sustenta a atuação do Ministério Público na defesa dos interesses sociais e individuais indisponíveis, calcada nos direitos fundamentais e na dignidade da pessoa humana. Cuida de estabelecer o conteúdo dos direitos fundamentais e o Estado, em especial em nosso país, comprometido este, constitucionalmente, com o estado democrático de direito; e em assegurar os direitos de primeira e segunda dimensões, bem assim os interesses difusos e coletivos.

O reconhecimento da adoção do modelo de estado de bem-estar social (welfare state) determinou aos governos o atendimento aos direitos públicos subjetivos, exigíveis perante o estado, por força da constituição. Esse atendimento se dá por meio da formulação, implementação e execução de políticas públicas. É apontada a complexidade do processo de implementação das políticas públicas, para além da compreensão usual de que ela se desenvolve na forma de um ciclo de fases e estágios, ao se constatar o caráter político do processo. O caráter complexo e político é identificado nas políticas de saúde brasileira, marcadas pela participação dos três níveis da federação, do controle social, pelo forte conteúdo intersetorial.

O capítulo 4 da obra dedica-se à noção de saúde, definindo-a, reconhecendo-a como direito, tratando de sua positivação no ordenamento jurídico, de seu conteúdo e sua caracterização. $\mathrm{O}$ autor introduz o tema da litigiosidade suscitada pelo direito à

\footnotetext{
1 Oliveira, Luciano Moreira, Ministério Público e Políticas de Saúde, Rio de Janeiro: Editora Lumen Juris. 2014. 176p.

2 Mestrando em Políticas Públicas em Saúde, Fundação Oswaldo Cruz (FIOCRUZ-Brasília). Subprocurador-Geral da República do Ministério Público da União. Brasília/ Distrito Federal. Brasil. E-mail: oswaldo.slv@gmail.com
} 
saúde que se costumou chamar de judicialização do direito à saúde, delimitando-o e apresentando um panorama do fenômeno no Brasil e exterior. Opina que o preceito constitucional que institui a universalidade e a integralidade do direito à saúde não pode ser limitado por lei, em especial a que limita as ações e serviços públicos de saúde àquelas que estão em consonância com os protocolos clínicos e diretrizes terapêuticas formulados pelo Poder Executivo.

Sobre o Ministério Público, a obra discorre sobre suas origens e perfil atual bem como arrola suas formas de atuação, estabelecendo a dicotomia entre o Ministério Público demandista e o Ministério Público Resolutivo, o primeiro preso ao sistema judicial estabelecendo controvérsias a serem resolvidas pelo Poder Judiciário e o segundo conciliador e mediador, tentando obter soluções de composição, conciliação e compromisso entre as partes interessadas.

Para o autor, o Ministério Público não é agente formulador de políticas públicas, muito menos na área da saúde. O papel do Ministério Público, não sendo o de formulador da política pública de saúde, é o de ser o agente controlador da conformidade da política pública com os preceitos constitucionais e ser o garantidor da máxima eficácia nas normas constitucionais diante das circunstâncias fáticas e jurídicas que informam determinada política pública de saúde, um potencial transformador da realidade social. Seu papel como agente controlador deve estar vinculado à atuação resolutiva.

Por fim cuida, apresentar os instrumentos normativos e a experiência, em números, gráficos e tabela, que guiam o MPMG, em sua opção pela estratégia da atuação resolutiva, dando ênfase à intersetorialidade e à participação de todos aqueles eventualmente envolvidos em uma controvérsia suscitada pelo direito à saúde. A obra reconhece um importante papel do Ministério Público em relação às políticas públicas, o de agente controlador e garantidor da submissão de uma determinada política pública aos preceitos constitucionais. E é justamente esta submissão que tem gerado alguma controvérsia entre os próprios membros do Ministério Público, tudo porque o direito à saúde é, nos termos do art. 196 da Constituição, garantido "mediante políticas sociais e econômicas que visem a redução do risco da doença e outros agravos (...)". Essas políticas públicas e sociais são externadas ou pelo Poder Executivo ou pelo Poder 
Legislativo (Lei 12.401/2011). Vale dizer: há muito o que se debater ainda sobre qual será a matriz constitucional que regerá a definição de integralidade e para onde penderá o Ministério Público ao desempenhar seu papel. 